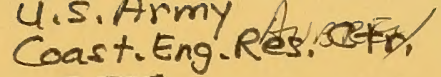

CETA

CETA 80-1

\title{
Maximum Wave Heights and Critical Water Depths for Irregular Waves in the Surf Zone
}

by

William N. Seelig

\section{COASTAL ENGINEERING TECHNICAL AID NO. 80-1 FEBRUARY 1980}

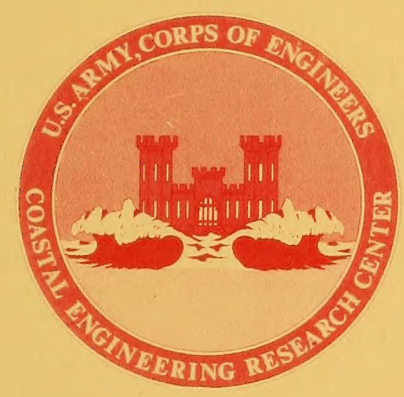

Approved for public release; distribution unlimited.

$T C$
330
.48

no. $80-1$
U.S. ARMY, CORPS OF ENGINEERS COASTAL ENGINEERING RESEARCH CENTER

\author{
Kingman Building
}

Fort Belvoir, Va. 22060 
Reprint or republication of any of this material shall give appropriate credit to the U.S. Army Coastal Engincering Research Center.

Limited free distribution within the United States of single copies of this publication has been made by this Center. Additional copies are available from:

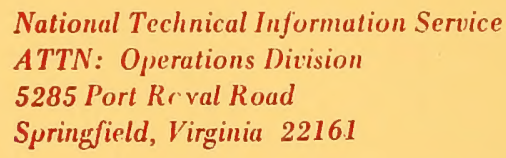

National Technical Information Service ATTN: Operations Division 5285 Port Rrval Road

Springfield, Virginia 22161

The findings in this report are not to be construed as an official Department of the Army position unless so designated by other authorized documents. 


\begin{tabular}{|c|c|}
\hline REPORT DOCUMENTATION PAGE & $\begin{array}{l}\text { READ INSTRUCTIONS } \\
\text { BEFORE COMPLETING FORM }\end{array}$ \\
\hline \begin{tabular}{l|l} 
1. REPORT NUMBER & 2. GOVT ACCESSION NO. \\
CETA $80-1$ &
\end{tabular} & 3. RECIPIENT'S CATALOG NUMBER \\
\hline \multirow{2}{*}{$\begin{array}{l}\text { 4. TITLE (and Subtitle) } \\
\text { MAXIMUM WAVE HEIGHTS AND CRITICAL WATER DEPTHS } \\
\text { FOR IRREGULAR WAVES IN THE SURF ZONE }\end{array}$} & $\begin{array}{l}\text { 5. TYPE OF REPORT \& PERIOD COVERED } \\
\text { Coastal Engineering } \\
\text { Technical Aid }\end{array}$ \\
\hline & 6. PERFORMING ORG. REPORT NUMBER \\
\hline $\begin{array}{l}\text { 7. AUTHOR(s) } \\
\text { William N. Seelig }\end{array}$ & 8. CONTRACT OR GRANT NUMBER(B) \\
\hline $\begin{array}{l}\text { 9. PERFORMING ORGANIZATION NAME AND ADDRES } \\
\text { Department of the Army } \\
\text { Coastal Engineering Research Center (CERRE-CS) } \\
\text { Kingman Building, Fort Belvoir, Virginia 22060 }\end{array}$ & $\begin{array}{l}\text { 10. PROGRAM ELEMENT, PROJECT, TASK } \\
\text { AREA \& WORK UNIT NUMBERS } \\
\text { F31538 }\end{array}$ \\
\hline \multirow{2}{*}{$\begin{array}{l}\text { 11. CONTROLLING OFFICE NAME AND ADDRESS } \\
\text { Department of the Army } \\
\text { Coastal Engineering Research Center } \\
\text { Kingman Building, Fort Belvoir, Virginia } 22060\end{array}$} & $\begin{array}{l}\text { 12. REPORT DATE } \\
\text { February } 1980\end{array}$ \\
\hline & $\begin{array}{l}\text { 13. NUMBER OF PAGES } \\
11\end{array}$ \\
\hline \multirow[t]{2}{*}{ 14. MONITORING AGENCY NAME A ADDRESS(If different from Controlling Office) } & $\begin{array}{l}\text { 15. SECURITY CLASS. (of this report) } \\
\text { UNCLASSIFIED }\end{array}$ \\
\hline & $\begin{array}{l}\text { 15a. DECLASSIFICATION/DOWNGRADING } \\
\text { SCHEDULE }\end{array}$ \\
\hline
\end{tabular}

16. DISTRIBUTION STATEMENT (of this Report)

Approved for pub1ic release; distribution unlimited.

17. DISTRIBUTION STATEMENT (of the abstract ontered in Block 20 , if different from Report)

18. SUPPLEMENTARY NOTES

19. KEY WORDS (Continue on reverse sido if necessary and identlfy by block number)

Design curves

Irregular waves
Wave heights

Waves 



\section{PREFACE}

Design curves for the maximum breaker height in the surf zone for monochromatic waves (based on the work of Goda, 1970) are given in Section 7.12 of the Shore Protection Manual (U.S. Army, Corps of Engineers, Coastal Engineering Research Center, 1977). This report presents similar curves for the magnitude and location of peak wave heights for irregular waves, based on the model of Goda (1975). This work was carried out as a part of the offshore breakwaters for shore stabilization program of the U.S. Army Coastal Engineering Research Center (CERC).

This report was prepared by William N. Seelig, Hydraulic Engineer, under the general supervision of Dr. R.M. Sorensen, Chief, Coastal Processes and Structures Branch.

Comments on this publication are invited.

Approved for publication in accordance with Public Law 166, 79th Congress, approved 31 July 1945, as supplemented by Public Law 172, 88th Congress, approved 7 November 1963 .

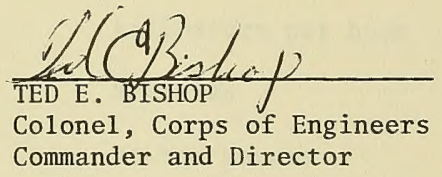


CONVERSION FACTORS, U.S. CUSTOMARY TO METRIC (SI) . . . . . . 5 SYMBOLS AND DEFINITIONS ..................... 6

I INTRODUCTION. . . . . . . . . . . . . . . . . . 7

II DESIGN CURVES ...................... 7

il I EXAMPle PROBlem . . . . . . . . . . . . . . . . . . 8

IV SUMMARY ....................... . . 11

TABLE

Predicted peak wave heights using irregular and monochromatic theories . . 11 FIGURES

1 Predicted nearshore wave heights using Goda's model . . . . . . 8

2 Peak values of wave height in the nearshore zone.......... 9

3 Water depth for the peak significant wave height. . . . . . . 10 
CONVERSION FACTORS, U.S. CUSTOMARY TO METRIC (SI)

UNITS OF MEASUREMENT

U.S. customary units of measurement used in this report can be converted to metric (SI) units as follows:

\begin{tabular}{|c|c|c|}
\hline Multiply & by & To obtain \\
\hline $\begin{array}{l}\text { inches } \\
\text { square inches } \\
\text { cubic inches }\end{array}$ & $\begin{array}{l}25.4 \\
2.54 \\
6.452 \\
16.39\end{array}$ & $\begin{array}{l}\text { millimeters } \\
\text { zentimeters } \\
\text { square centimeters } \\
\text { cubic centimeters }\end{array}$ \\
\hline $\begin{array}{l}\text { feet } \\
\text { square feet } \\
\text { cubic feet }\end{array}$ & $\begin{array}{l}30.48 \\
0.3048 \\
0.0929 \\
0.0283\end{array}$ & $\begin{array}{l}\text { centimeters } \\
\text { meters } \\
\text { square meters } \\
\text { cubic meters }\end{array}$ \\
\hline $\begin{array}{l}\text { yards } \\
\text { square yards } \\
\text { cubic yards }\end{array}$ & $\begin{array}{l}0.9144 \\
0.836 \\
0.7646\end{array}$ & $\begin{array}{l}\text { meters } \\
\text { square meters } \\
\text { cubic meters }\end{array}$ \\
\hline $\begin{array}{l}\text { miles } \\
\text { square miles }\end{array}$ & $\begin{array}{l}1.6093 \\
259.0\end{array}$ & $\begin{array}{r}\text { kilometers } \\
\text { hectares }\end{array}$ \\
\hline knots & 1.852 & kilometers per hour \\
\hline acres & 0.4047 & hectares. \\
\hline foot-pounds & 1.3558 & newton meters \\
\hline millibars & $1.0197 \times 10^{-3}$ & kilograms per square centimeter \\
\hline ounces & 28.35 & grams \\
\hline pounds & $\begin{array}{l}453.6 \\
0.4536\end{array}$ & $\begin{array}{l}\text { grams } \\
\text { kilograms }\end{array}$ \\
\hline ton, long & 1.0160 & metric tons \\
\hline ton, short & 0.9072 & metric tons \\
\hline degrees (angle) & 0.01745 & radians \\
\hline Fahrenheit degrees & $5 / 9$ & Celsius degrees or Kelyins ${ }^{1}$ \\
\hline
\end{tabular}

${ }^{1}$ To obtain Celsius (C) temperature readings from Fahrenheit (F) readings, use formula: $C=(5 / 9)(F-32)$.

To obtain Kelvin $(K)$ readings, use formula: $K=(5 / 9)(F-32)+273.15$. 


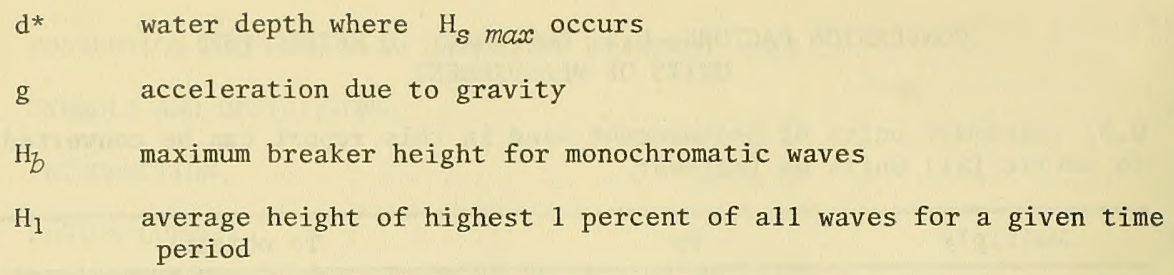

$\mathrm{H}_{1} \max$ peak value of $\mathrm{H}_{1}$

$\mathrm{H}_{0} \quad$ deepwater significant wave height

$\mathrm{H}_{S} \quad$ significant wave height defined as the average of the highest one-third waves

$\mathrm{H}_{S}$ max peak value of $\mathrm{H}_{S}$

$\mathrm{T}_{p} \quad$ wave period defined as the period of peak energy density for irregular waves

m slope of the bottom 


\section{Williom Ny. Seelig}

\section{INTRODUCTION}

The Shore Protection Manual (U.S. Army, Corps of Engineers, Coastal Engineering Research Center, 1977) ${ }^{l}$ gives methods for estimating wave height nearshore due to monochromatic waves, based on the work of Goda $(1970)^{2}$. However, the action of irregular waves in the surf zone is very complex, involving the interaction of wave shoaling, breaking, and setup; re-formation of broken waves; surf beat; and other mechanisms. Goda $(1975)^{3}$ proposed a model for predicting wave height distributions and wave height parameters in the nearshore zone for the case of continuously shallowing profiles. Goda's model assumes that the (a) equivalent deepwater significant wave height and period are known; (b) deepwater wave heights have a Rayleigh distribution; (c) average beach slope onehalf to one wavelength seaward of the point of interest is known; (d) surf beat, wave setup, and breaking limits can be described by empirical formulas; (e) wave shoaling is nonlinear; and (f) broken waves re-form at lower heights. Using these assumptions, a numerical procedure was developed to predict nearshore wave heights (see Seelig and Ahrens, 1979) ${ }^{4}$. Limited testing of the model with field and laboratory data suggests that Goda's model gives useful estimates of nearshore wave heights.

\section{DESIGN CURVES}

Calculations of nearshore wave conditions using Goda's (1975) ${ }^{5}$ model show that wave height parameters reach a maximum or peak value at one point along the profile. For example, an irregular wave condition with a deepwater significant wave height, $\mathrm{H}_{o}$, and a period of peak energy density, $\mathrm{T}_{p}$, has a peak value of significant wave height, $\mathrm{H}_{S} \max$, at a water depth, $\mathrm{d}^{*}$ (Fig. 1). This would be an especially poor location to build a structure or site any other activity sensitive to wave height, because the significant wave height reaches its largest value at this point. $\mathrm{H}_{1}$ shown in the figures is defined as the

\footnotetext{
${ }^{1}$ U.S. ARMY, CORPS OF ENGINEERS, COASTAL ENGINEERING RESEARCH CENTER, Shore Protection Manual, 3d ed., Vols. I, II, and III, Stock No. 008-022-00113-1, U.S. Government Printing Office, Washington, D.C., 1977, 1,262 pp.

${ }^{2}$ GODA, Y., "A Synthesis of Breaker Indices," Transactions of the Japanese Society of Civil Engineers, Vo1. 2, Pt. 2, 1970.

${ }^{3}$ GODA, Y., "Irregular Wave Deformation in the Surf Zone," Coastal Engineering in Japan, Vo1. 18, 1975, pp. 13-26.

${ }^{4}$ SEELIG, W.N., and AHRENS, J., "Estimating Nearshore Conditions for Irregular Waves," U.S. Army, Corps of Engineers, Coastal Engineering Research Center, Fort Belvoir, Va. (in preparation, 1980).

${ }^{5}$ GODA, Y., op. cit.
} 


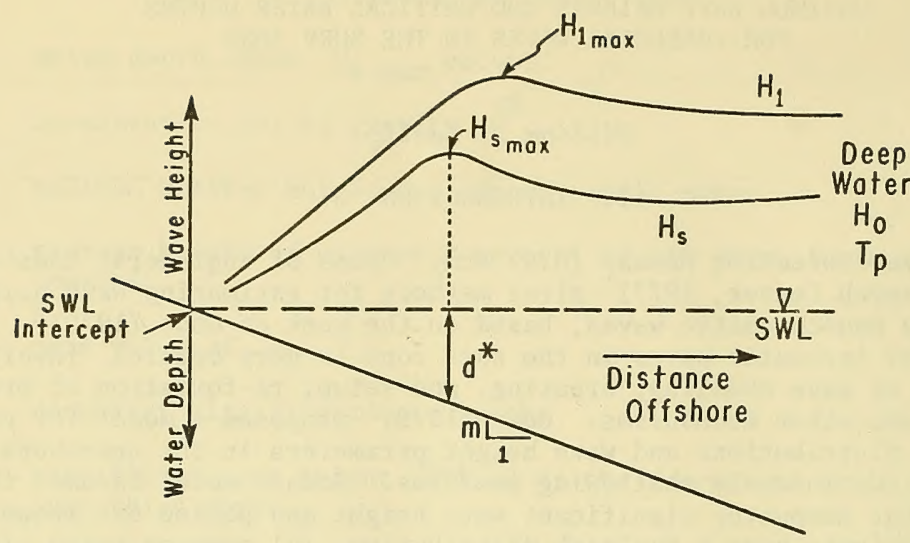

Figure 1. Predicted nearshore wave heights using Goda's model.

average of the highest 1 percent of the waves and is the wave height with an exceedance probability of approximately 1/260. Goda's mode1 predicts that the peak value of $\mathrm{H}_{1}$ occurs just seaward of $\mathrm{d}^{*}$ (Fig. 1).

Figure 2 gives the design curves for $H_{S} \max$ and $H_{1} \max$ as a function of deepwater wave steepness and beach slope. These curves show that the peak wave heights decrease as the wave steepness increases and the beach slope becomes flatter. The dimensionless water depth where the peak significant wave height occurs becomes smaller as the beach slope or wave steepness increases, except for the steepest waves (Fig. 3).

\section{III . EXAMPLE PROBLEM}

GIVEN: Wave conditions of $\mathrm{H}_{O}=6.56$ feet $(2.0$ meters $)$ and $\mathrm{T}_{p}=10$ seconds with a beach slope, $\mathrm{m},=1 / 100$.

FIND: The peak significant and maximum wave heights in the surf zone and their locations.

SOLUTION: For this example:

$$
\mathrm{H}_{\mathrm{O}} / \mathrm{gT}_{\hat{p}}^{2}=2.0 /\left(9.8 * 10^{2}\right)=0.002 \text {. }
$$

From Figure 2,

$$
\frac{\mathrm{H}_{s} \max }{\mathrm{H}_{0}}=1.18 \text { or } \mathrm{H}_{S} \max =7.7 \text { feet }(2.3 \text { meters }) \text {, }
$$

and

$$
\frac{\mathrm{H}_{1} \max }{\mathrm{H}_{O}}=1.81 \text { or } \mathrm{H}_{1} \max =11.8 \text { feet }(3.62 \text { meters }) \text {. }
$$




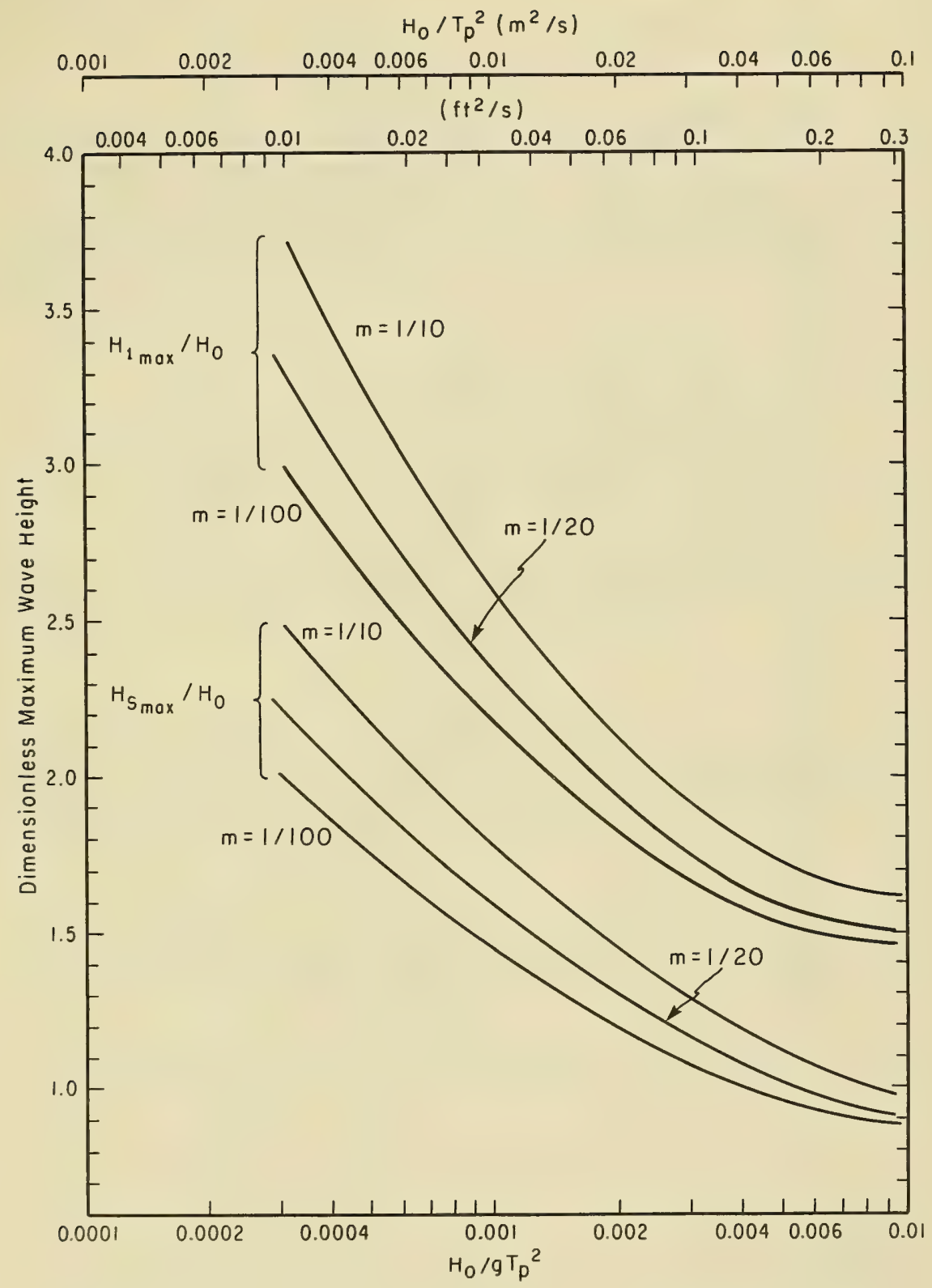

Figure 2. Peak values of wave height in the nearshore zone. 


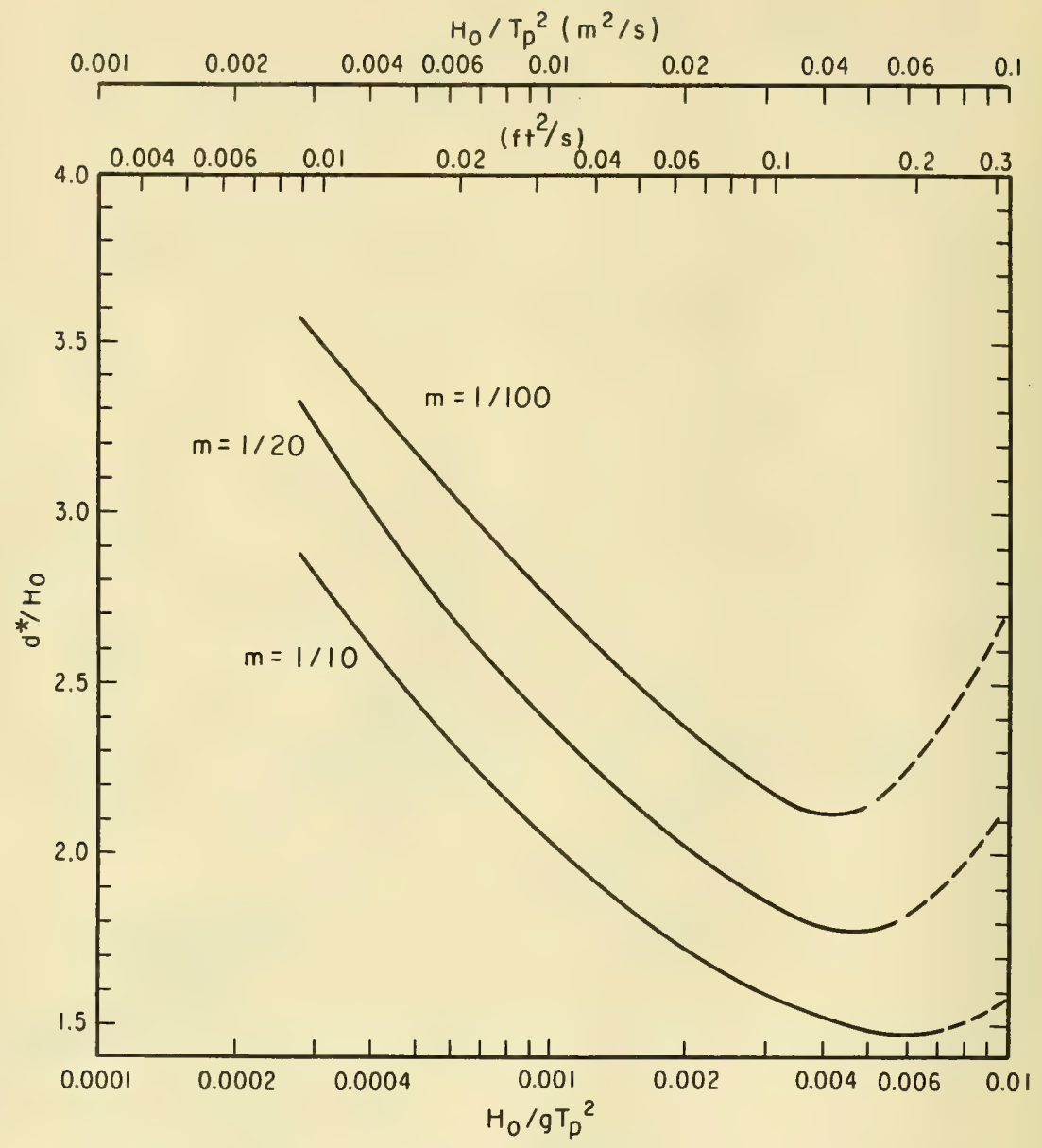

Figure 3. Water depth for the peak significant wave height. 
From Figure 3,

$$
\frac{\mathrm{d}^{*}}{\mathrm{H}_{O}}=2.36 \text { or } \mathrm{d}^{*}=15.5 \text { feet }(4.72 \text { meters })
$$

which occurs 1,550 feet (472 meters) offshore of the beach stillwater leve1 (SWL) intercept for a $1 / 100$ slope beach.

Note that monochromatic theory predicts a breaker height, $\mathrm{H}_{b}$, (Fig. 7-3 in U.S. Army, Corps of Engineers, Coastal Engineering Research Center, 1977) ${ }^{6}$ that occurs between the peak significant and maximum one percent heights (see Table).

Table. Predicted peak wave heights using irregular and monochromatic theories $(\mathrm{T}=10$ seconds; $\mathrm{m}=1 / 20)$.

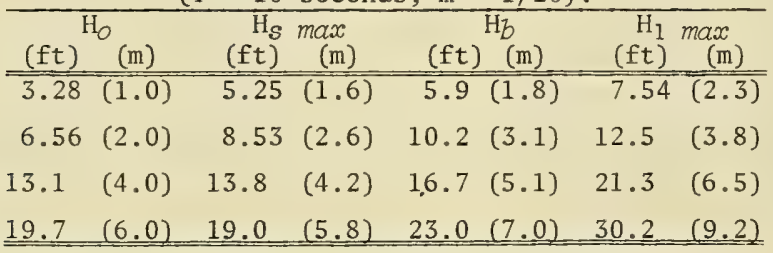

IV. SUMMARY

The mode1 of Goda $(1975)^{7}$ for predicting heights of irregular waves in the surf zone is used to determine the peak significant and maximum wave heights and location where peak wave heights will occur.

\footnotetext{
${ }^{6}$ U.S. ARMY, op. cit., p. 7.

${ }^{7}$ GODA, Y., op. cit., p. 7 .
} 



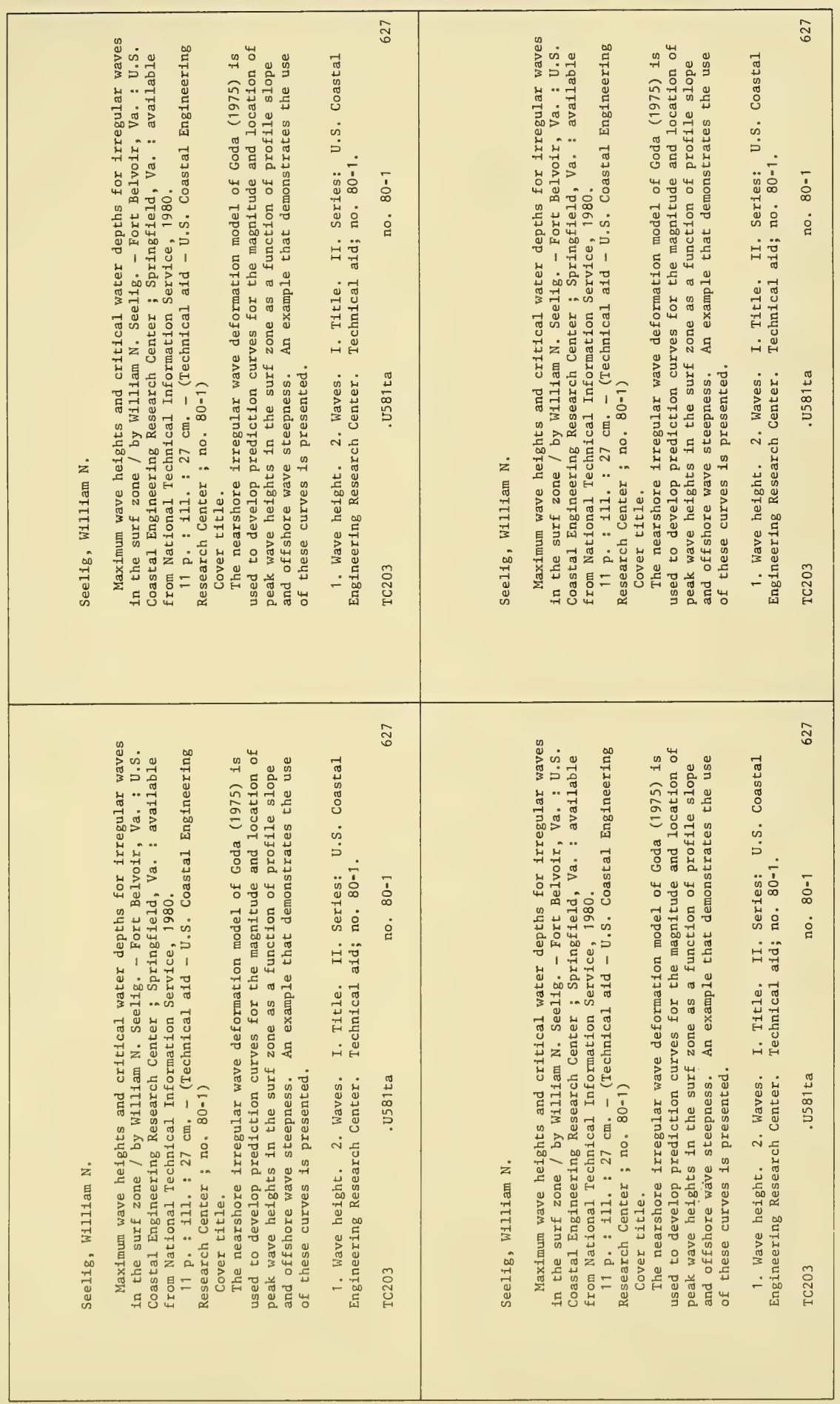



क. तु

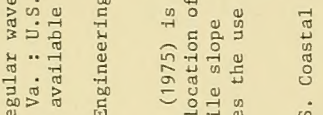

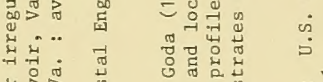

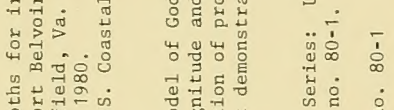

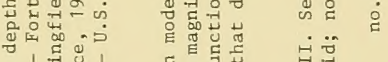

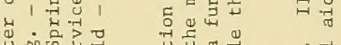

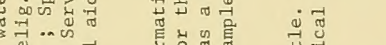

गี

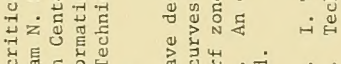

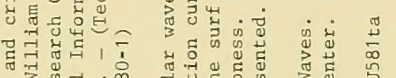

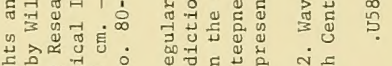

$\dot{z}$ की

도에

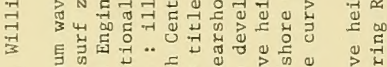

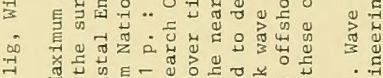

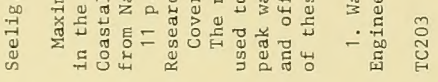

包

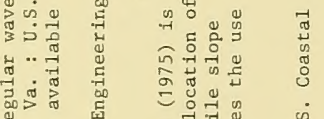

落

प्रेज्रें

밈

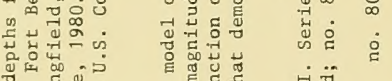

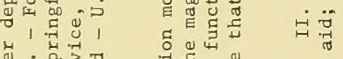

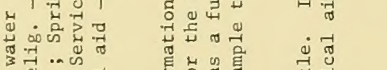

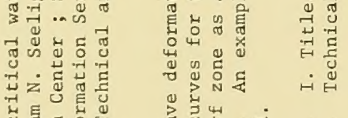

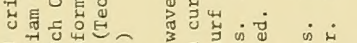

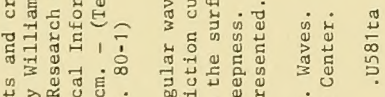

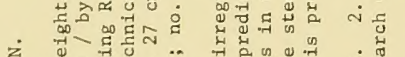

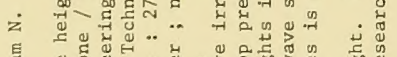

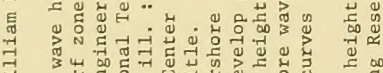

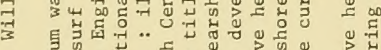

.

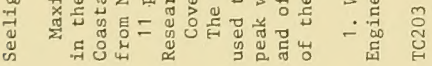




